HISPANIA. Revista Española de Historia, 2009, vol. LXIX, núm. 233, septiembre-diciembre, págs. 793-820, ISSN: 0018-2141

\title{
ENCONTRANDO EL NORTE. MANUEL LLANEZA Y LA INFLUENCIA FRANCESA EN EL SINDICALISMO ESPAÑOL DE PRINCIPIOS DEL SIGLO XX
}

\author{
JORGE MuÑiz SÁNCHEZ \\ Université Paris 1 (Panthéon-Sorbonne) / CNRS
}

RESUMEN: La primera década del siglo XX babía mostrado la incapacidad de los mineros asturianos para crear organizaciones útiles y duraderas, porque sistemáticamente éstas, de carácter puramente local, mal organizadas y sin recursos, eran destruidas por las empresas tras cada huelga fallida. Cuando en 1910 se fundó el Sindicato de los Obreros Mineros de Asturias (SOMA), las condiciones socioeconómicas no babian cambiado en lo sustancial desde principios de la centuria: el tipo de trabajador y sus condiciones de vida seguían siendo básicamente los mismos, así como los sistemas de trabajo. Sin embargo, el SOMA tuvo un éxito que sus antecesores no habian conocido, luego se debe buscar el motivo de su pervivencia en su sistema organizativo. Su consolidación se debió a sus estructuras y medios de acción innovadores, importados por Manuel Llaneza de las minas del Norte de Francia, donde había trabajado los dos años anteriores. Gracias a eso pudo crear el primer sindicato de industria de España.

Palabras Clave: Sindicalismo. Minas. Asturias. Nord - Pas-de-Calais. Sindicato de los Obreros Mineros de Asturias (SOMA). Socialismo.

Finding THE NORTH. MANUEL LLANEZA AND THE FRENCH INFLUENCE ON SPANISH TRADES UNIONISM IN THE EARLY 20TH CENTURY

ABSTRACT: The first decade of the 20th century highlighted the inability of Asturian miners to create useful and lasting organizations, which were systematically destroyed by the companies after every unsuccessful strike due to their local character, poor organisation and lack of resources. In 1910, when the Asturian Mineworkers Union (SOMA) was founded, socioeconomic conditions had not substantially

Jorge Muñiz Sánchez es investigador del Plan Clarín de la Fundación para el Fomento en Asturias de la Investigación Científica Aplicada y la Tecnología (FICYT), con destino en el Centre d'Histoire des Sciences et d'Histoire des Techniques de la Université Paris 1 (Panthéon-Sorbonne) / CNRS. Dirección para correspondencia: 9 rue Malher, 75181, Paris.E-mail: jorgemunizsanchez@gmail.com 
changed since the beginning of the century: working systems, workers and their living conditions were basically the same. However, SOMA succeeded where its predecessors hadn't, and this success was due to the innovative structures and means of action imported by Manuel Llaneza from mines in the North of France, where he had worked the previous two years. These measures allowed him to create the first industrial trade union in Spain.

KEY WORDS: Trade union movement. Mining. Asturias. Nord Pas-de-Calais. Asturian Mineworkers Union (SOMA). Socialism.

Cuando se habla o se escribe sobre Manuel Llaneza se hace obligado destacar la importancia capital que tuvo para el movimiento obrero asturiano - y aún español— del primer tercio del siglo XX. Las cláusulas de este tipo a menudo se convierten en un dogma vacío ${ }^{1}$, pero en este caso está lejos de ser así, ya que realmente su actividad cambió la faz del sindicalismo de la región e incluso del país. Su obra fue la creación de un sindicato de industria, capaz de reunir a todos los trabajadores de un sector económico, frente a las pequeñas agrupaciones locales o de empresa que existían anteriormente. Esta organización fue la primera de estas características no ya en Asturias, sino en España, y cosechó un rápido éxito gracias a las ventajas que ofrecía con respecto a lo entonces existente ${ }^{2}$.

¿De dónde surgió la idea de crear en Asturias un sindicato así? En Europa este tipo de asociaciones tenía ya varias décadas de existencia cuando Llaneza fundó el Sindicato de los Obreros Mineros de Asturias (en adelante SOMA). De hecho, hacía ya dos decenios que se celebraban congresos mineros internacionales en los que las organizaciones francesas, belgas o inglesas -e incluso algunas que padecían sistemas políticos realmente opresivos, como las alemanas - intercambiaban ideas mientras el sindicalismo minero español se encontraba en una fase balbuceante e ignorante de todos estos debates y métodos organizativos $^{3}$. Todo cambió porque Llaneza vivió y trabajó en las minas del Norte de Francia entre 1908 y 1910, donde existía una sólida organización de estas características en la que pudo inspirarse ampliamente para fundar, apenas

1 Lo que tiene de lugar común lo señala PÉREZ LEDESMA, Manuel, El obrero consciente: dirigentes, partidos y sindicatos en la Segunda Internacional, Madrid, Alianza, 1987.

2 Véase Moradiellos, Enrique, El Sindicato de los Obreros Mineros de Asturias, 1910-1930, Oviedo, Universidad, 1986, pág. 43, y SABORIT, Andrés, Asturias y sus hombres, Toulouse, UGT/CIOSL, 1964, pág. 155. A los pocos años era considerado por el Consejo Nacional de Combustibles «la organización socialista de más fuerza del país». AldECOA, Miguel et al., Dictamen oficial sobre la industria hullera en Asturias, Madrid, Imprenta Clásica Española, 1926, pág. 217.

3 KOURCHID, Olivier, «Régulation des conflits dans l'industrie houillère en France et en Europe dans les années 1890-1900. Spécificités nationales et comparaisons internationales», en: FORTUNET, Françoise (dir.), Un siècle de pratiques de régulation des conflits collectifs du travail (La loi du 27 décembre 1892 en débat), Dijon, Publications de l'Université de Bourgogne, 2001, págs. 85-111. 
regresado a Asturias, su sindicato. Esto es algo que ha sido reiteradamente señalado en la historiografía que se ha ocupado de la materia, ya fuera de una forma más directa o colateral ${ }^{4}$. Ahora bien, hay que decir que nos encontramos ante una afirmación un tanto doctrinaria, porque no se ha hecho más que repetir que Llaneza efectivamente estuvo allí y que allí debió aprender mucho sobre el sindicalismo moderno, pero sin aportar concreción alguna. En ciertas ocasiones cometiendo incluso alguna inexactitud que posteriormente habrá oportunidad de señalar. Lo que sigue es un intento de constatar en qué pudo consistir específicamente la influencia de los sindicatos de la región Nord - Pas-deCalais en el sindicalista langreano y, por extensión, en Asturias y en España.

\section{LA INFANCIA DE LAS ORGANIZACIONES OBRERAS ASTURIANAS ${ }^{5}$}

En la última década del siglo XIX aparecen las primeras agrupaciones locales en la zona central de Asturias, favorecida su propaganda por las repercusiones de la Guerra de Cuba. En 1902 se contaban setenta sindicatos con unos cuatro mil afiliados ${ }^{6}$. Sin embargo, esta primera floración tenía unas raíces endebles que serán fácilmente arrasadas por las empresas y en particular, aunque no exclusivamente ${ }^{7}$, las mineras. En 1903 la sección socialista de Arnao, una de las más nutridas, se vio prácticamente reducida a cenizas ${ }^{8}$. Ese mismo año se produjo un gran conflicto de resultado nefasto por un descenso salarial en Duro Felguera. Igualmente, una reducción de las remuneraciones en Fábrica de Mieres está en el origen de la conocida «huelgona» de 1906, que resultó aún más dañina para el movimiento obrero asturiano. Desencadenada en un momento de exceso de producción, la empresa podía postergar prácticamente sine die la reanudación de los trabajos, mientras los mineros estaban faltos de elementos de resistencia. La catástrofe fue aprovechada por la empresa para despedir a toda la plantilla —incluido Manuel Llaneza, que militaba en el Partido

\footnotetext{
${ }^{4}$ Además de las obras citadas de Moradiellos, Saborit y Pérez Ledesma, son de obligada revisión SuÁrez Iglesias, Ramiro, Vida, obra y recuerdos de Manuel Llaneza, Oviedo, Biblioteca Popular Asturiana, 1979 (1. ${ }^{a}$ ed. 1932); RUIZ GONZÁLEZ, David, El movimiento obrero en Asturias: de la industrialización a la Segunda República, Oviedo, Asociación de Amigos de Asturias, 1968; SHUBERT, Adrian, Hacia la revolución. Orígenes sociales del movimiento obrero en Asturias, 1860-1934, Barcelona, Crítica, 1984 y RoDrígueZ, Jesús Jerónimo, La cultura sindical en Asturias, 1875-1917, Oviedo, RIDEA, 2000.

${ }_{5}^{5}$ El presente trabajo es deudor de las valiosas aportaciones que sobre el borrador realizaron los profesores Jorge Uría y Rubén Vega. Obviamente, los errores o carencias que pueda contener son responsabilidad exclusiva del autor.

${ }^{6}$ SABOrit, Asturias..., pág. 22 y SHubert, Hacia..., págs. 136-137.

7 El desastre de la huelga general de 1901 en Gijón lo testimonia. Vid. Moradiellos, El Sindicato..., págs. 38-39.

${ }^{8}$ De la Madrid Álvarez, Juan Carlos, Avilés: una historia de mil años, Avilés, Azucel, 1997, pág. 190 .
} 
Socialista desde 1903 y había tomado parte en el movimiento a su pesar9creándose un «gabinete negro» encargado de evitar la reincorporación de cualquier elemento sospechoso. El sindicato perdió setecientos de los ochocientos afiliados que tenía ${ }^{10}$. En el ámbito regional, el movimiento obrero se encontraba prácticamente desarticulado.

¿Cómo es posible que unas organizaciones obreras florecientes, en una región en pleno desarrollo industrial, pudieran ser casi totalmente destrozadas en tres años? La primera causa fueron las carencias organizativas, ya que hablamos de una débil constelación de entidades locales, apenas federadas entre sí y sin dinero. Cualquiera podía desencadenar una huelga en cualquier momento. No se tenía en cuenta la situación ni siquiera al nivel más cercano, lo que abocaba a errores tácticos tan graves como el de $1906^{11}$. En segundo lugar, los primeros años del siglo fueron un período poco favorable sindicalmente, porque a las empresas les sobraban producción y trabajadores, por lo que es más que verosímil que en algunos casos provocaran las huelgas para laminar a los sindica$\operatorname{tos}^{12}$. Por último, es evidente el retraso en la organización obrera con respecto a buena parte de Europa, lo que está íntimamente relacionado con la causa citada en primer lugar. En contraste, la cuenca de Pas-de-Calais, puesta en explotación a mediados del siglo XIX, contaba con un fuerte sindicato de industria desde $1889^{13}$.

¿A qué se deben esos veinte años de diferencia en la adopción de un sindicalismo moderno? En Asturias sigue habiendo un elevado número de obreros mixtos, que combinan la actividad agropecuaria con la asalariada en las minas,

9 A la memoria de Manuel Llaneza, en el 10 aniversario de su muerte, 1932, pág. 3.

10 ShUberT, Hacia..., págs. 137-139. Saborit parece tener muy claras las causas de la derrota: «faltaba dinero y la organización estaba prendida con alfileres», SABORIT, Asturias..., pág. 144. Ciges retrata muy bien el conflicto y sus consecuencias, incidiendo en la impunidad con la que Fábrica de Mieres controlaba todos los aspectos de la vida cotidiana: «-iCómo se conoce que viene usted de fuera!... ¿ ¿Ha olvidado a los espías? — La plaza está desierta. — ¿Y puede usted asegurar que nadie observa escondido en alguna esquina? ¿Está cierto de que por los resquicios de las puertas ó á la altura de las ventanas no hay alguien que nos mira?», CigES APARICIO, Manuel, Los vencedores, Madrid, M. Pérez Villavicencio, 1908, pág. 51; del mismo autor, Los vencidos, Madrid, Librería de los sucesores de Hernando, 1910.

${ }^{11}$ Las causas estaban claras para Llaneza: «Entre las sociedades locales (...) no existía (...) un nexo orgánico (...)» y por ello «los obreros, agotadas nuestras energías y nuestras fuerzas, volvíamos al trabajo vencidos (...)», LLANEZA ZAPICO, Manuel, «Mirando al porvenir», El Socialista, 15-91913, recogido en: LlaneZA, Manuel, Escritos y discursos, Oviedo, Fundación José Barreiro, 1985, págs. 73-74. La misma idea en LlaneZA ZAPICO, Manuel, "Consideraciones», El Minero de la Hulla, 19 (febrero 1916), págs. 1-3. Idénticos motivos esgrime DE LA FuENTE, José, «Origen y actuación de nuestro sindicato", El Minero de la Hulla, 39 (octubre 1917), págs. 6-10.

12 SHUbert, Hacia ..., págs. 137-139.

${ }_{13}$ Como introducción al respecto, véase MiCHel, Joël, «Syndicalisme minier et Politique dans le Nord - Pas-de-Calais: le cas Basly (1880-1914)», Le Mouvement Social, 87 (Réformismes et Réformistes Français, Apr.-Jun. 1974). 
a menudo además contemplada como subsidiaria de la primera ${ }^{14}$. Según el profesor David Ruiz, estos trabajadores con un arraigado sentido de la propiedad debido a su cultura campesina y que, gracias a los productos de la tierra, se encontraban más protegidos de las privaciones que los obreros proletarizados, serían menos sensibles a las reivindicaciones sindicales. Ésta es la tesis tradicional, adoptada por algunos autores relevantes ${ }^{15}$. Para otros, como Adrian Shubert, tal explicación es insuficiente porque cuando se funda el SOMA en 1910 no se había producido ningún cambio significativo en la situación descrita, ya que el obrero mixto sigue siendo ampliamente predominante al menos hasta la Primera Guerra Mundial -época en la que el sindicato estaba ya plenamente arraigado- y tampoco se constatan novedades en la organización del trabajo o alguna otra variable sustancial ${ }^{16}$. El problema es que la crítica de Shubert, aparentemente bien fundada, no aporta ninguna respuesta al interrogante que abre.

Aceptando que el campesino-obrero pueda resultar más pacífico en términos generales, sí parece, en cualquier caso, que tampoco constituye un elemento inerte ni presto a dejarse hacer sin ninguna cortapisa. De hecho, las revueltas laborales en la región están documentadas ya en el tercer cuarto del siglo $\mathrm{XIX}^{17}$. Cabe pensar, por consiguiente, que la imagen idílica del pacífico campesino-obrero es una simplificación. No en vano, es a partir de este sustrato que a finales del XIX aparecen algunas primitivas organizaciones. Si éstas no medran es más bien debido a su propia debilidad organizativa y a su bisoñez, como se ha indicado al hablar de las apocalípticas huelgas de 1903-1906, bien aprovechadas por la patronal. Entonces, ¿qué hay de nuevo en 1910? Hasta entonces, quienes se acercaban a alguna de las incipientes asociaciones, sin mucho conocimiento ni convicción y empujados por la insatisfacción, terminaban por abandonarla al primer revés - que por otra parte no solía hacerse esperar- al juzgarla inútil. Pero el descontento y las ganas de mejora existían. Para convencer a los reticentes sólo era necesario un adecuado esquema de encuadramiento, que es lo que aportará Llaneza a su vuelta. Como diría un diario

${ }^{14}$ URÍA GONZÁLEZ, Jorge, «Asturias, 1898-1914. El final de un campesinado amable», Hispania, 212 (2002). Las causas y consecuencias de esta situación, en especial los efectos perniciosos sobre la actividad de las empresas mineras, son prolijas y se alejan de nuestro objetivo en estas páginas. Para una visión más exhaustiva a partir de contemporáneos, vid. ADARO Y MAGRO, Luis, Los carbones nacionales y la marina de guerra, Oviedo, Escuela Tipográfica del Hospicio Provincial, 1912 y GASCUE y MURGA, Francisco, «La Industria Carbonera en Asturias (El Obrero)», Revista Minera, Tomo I, serie C (1883). Desde una interesante perspectiva antropológica, GARCía GARCía, José Luis, «Mineros alleranos: de los diferentes segmentos sociales a la construcción de la comunidad», en: VV. AA., Los últimos mineros. Un estudio antropológico sobre la mina en España, Madrid, CIS, 2002. Imprescindible, sobre las repercusiones sociales, SIERRA ÁLVAREZ, José, El obrero soñado: Ensayo sobre el paternalismo industrial (Asturias, 1860-1917), Madrid, Siglo XXI de España, 1990.

15 RuIZ GONZÁleZ, El movimiento obrero..., pág. 96; MORADIELlos, El Sindicato..., págs. 32-33.

16 SHUBeRT, Hacia la revolución..., pág. 132.

17 SHUberT, Hacia la revolución..., pág. 132; RuIz GONZÁLEZ, El movimiento obrero..., pág. 96. 
regional, «el modesto guerrillero de 1908 volvió de Francia en 1910 con los entorchados de general» ${ }^{18}$.

\section{LO QUE SE HA ESCRITO SOBRE LA EXPERIENCIA FRANCESA DE LLANEZA}

El futuro líder había sido despedido, como se ha visto, en la «huelgona» de 1906 y esto le había impedido encontrar empleo en la región ${ }^{19}$. Por este motivo se fue a trabajar a las minas de Puertollano, donde sólo obtuvo serios problemas económicos. De vuelta a Mieres, ejerció algún tiempo como vendedor ambulante de libros y periódicos hasta que en 1908 su compañero y amigo Juan Luis González — que mantenía correspondencia con Eustaquio de la Fuente, residente en Francia - le aconsejó probar suerte en la república vecina, adonde decidió viajar en compañía de su mujer y su entonces única hija. Allí permaneció dos años ${ }^{20}$. Ninguna información adicional relevante sobre su peripecia personal encontramos en las obras publicadas hasta el momento. Ni en qué localidad vivió, ni en qué empresa trabajó, ni mayores precisiones sobre el período. Sólo gracias a una noticia de El Noroeste sabemos que fue minero de la Société Houillère de Liévin, cuya concesión se ubicaba en el centro de la cuenca (ver imagen 1$)^{21}$. Es verosímil que la virulenta huelga registrada allí a finales de julio y principios de agosto precipitara su regreso si la decisión, como parece probable, estaba tomada ya ${ }^{22}$. En cualquier caso, desde el principio da la sensación de que Llaneza planea volver a Asturias con idea de organizar un nuevo sindicato en un plazo breve ${ }^{23}$.

Lamentablemente, salvo la compañía y las fechas de llegada y partida, conocidas por la bibliografía y hemerografía citada, no tenemos ninguna otra información concreta sobre su estancia. No dejó nada escrito en los periódicos sindicales de Nord - Pas-de-Calais. Tampoco los archivos de la compañía de Liévin conservados en el Centre des Archives du Monde du Travail o en el Centre Historique Minier de Lewarde guardan ninguna referencia. La documenta-

${ }_{18}$ El Noroeste, 1-5-1914, pág. 1.

19 Llaneza se hizo notar participando en mítines (El Noroeste, 12-2-1906, pág. 4) y al terminar la huelga no pudo volver a trabajar en Asturias, ya que las empresas al descubrir su verdadera identidad le despedían, como le sucedió en abril de 1906 (El Noroeste, 16-4-1906, pág. 4). En cualquier caso, ya antes de la «huelgona» había padecido este tipo de persecuciones laborales en las minas de Teverga (El Noroeste, 1-5-1914, pág. 1).

${ }_{20}$ A la memoria de Manuel Llaneza, en el 10 aniversario de su muerte, 1932, pág. 4. SUÁrez IgLESIAS, Vida ..., pág. 25; SABORIt, Asturias..., pág. 146.

${ }^{21}$ El Noroeste, 25-1-1931, pág. 3.

22 Sobre la huelga, La Voix du Mineur, 6-8-1910 y 13-8-1910 y Le Réveil du Nord, 26-7-1910 a 7-8-1910.

${ }^{23}$ Recién llegado, en octubre y noviembre de 1908, publicaba sendos artículos animando a los mineros asturianos a adoptar las nuevas formas de organización que él estaba viendo. LLANEZA ZAPICO, Manuel, "Cuestiones mineras», La Aurora Social, 9-10-1908 y "Ventajas de la organización», La Aurora Social, 20-11-1908. 
ción sobre extranjeros y movimientos sociales de los archivos departamentales y la policía también es muda al respecto. Por último, y quizá sea esto lo más sorprendente, la Agence Nationale pour la Garantie des Droits des Mineurs, la institución que en principio conserva todas las libretas con la vida laboral de los mineros, tampoco tiene constancia de la existencia de Manuel Llaneza. Por tanto, salvo que medie alguna siempre posible merma documental, lo más probable es que el sindicalista, emigrante forzoso a causa de la lista negra de Fábrica de Mieres, diera un nombre falso —algo para lo que tendría ya una cierta práctica- para evitarse problemas.

\section{IMAGen 1. Plano De LA CUENCA HUlLERA Nord - PAS-DE-CALAIS}

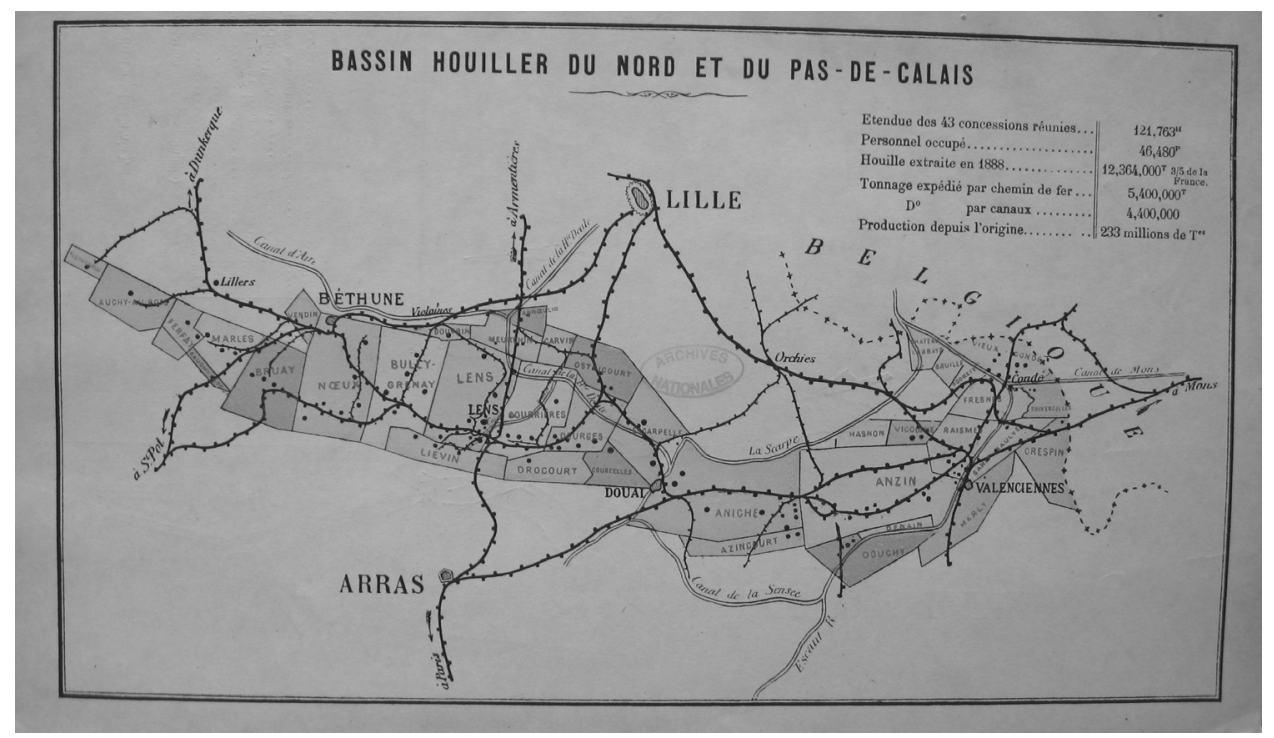

Se aprecia la ubicación de Liévin en el centro. Société des Mines de Lens, Exposition Universelle de 1889. Notice sur la Société des Mines de Houille de Lens E Douvrin (Pas-de-Calais), Lille, 1889.

Respecto a la influencia que pudo recibir de los sindicatos del Norte de Francia, las noticias son igualmente escuetas. Apenas tres magros rasgos característicos se nos presentan, de los que el último que se citará es a todas luces erróneo. Se destaca algo ya mencionado y que, efectivamente, resulta crucial: allí aprendió la centralización de recursos y decisiones, que evita el desencadenamiento de conflictos locales inoportunos que puedan comprometer la estrategia global o, incluso, la pervivencia de la organización. Por eso entre los «deberes del sindicado» se encontraba «no hacer paros ni provocar conflictos que puedan perjudicar al Sindicato, guardando siempre la más estricta disciplina en 
todos los casos» ${ }^{24}$. Llaneza no se cansaba de recordar, en las páginas de su boletín, que el SOMA corría un grave riesgo si no se evitaban las huelgas espontáneas $^{25}$. Igualmente, la centralización de las cotizaciones, reteniendo las secciones locales lo imprescindible para su funcionamiento, permitía afrontar los paros de manera solvente ${ }^{26}$. La procedencia de esta forma de organizarse no ofrece duda alguna:

Los fundadores del Sindicato, inspirándose en los sindicatos extranjeros y en las enseñanzas que se derivan de lo acontecido en Asturias anteriormente, idearon la nueva organización en los moldes del centralismo para evitar que fuese flor de un día el nuevo despertar de los mineros asturianos ${ }^{27}$.

En segundo lugar, el fracaso de 1906 y la experiencia francesa habrían hecho madurar a Llaneza también en el sentido de descartar la posibilidad de un cambio social brusco. En esos años abandonó sus concepciones de juventud, en absoluto revolucionarias pero sí un tanto mesiánicas e indefinidas, por un sentido mucho más pragmático de búsqueda de mejoras inmediatas ${ }^{28}$. De hecho, en noviembre de 1908 publicaba, encontrándose ya en Pas-de-Calais, un artículo en La Aurora Social en el que animaba a los mineros asturianos a organizarse para obtener logros concretos y limitados, semejantes a los que sus colegas de esta provincia francesa disfrutaban: un jornal mínimo, casa de la empresa, retiro a los treinta años de trabajo... ${ }^{29}$. En cualquier caso, sería más que arriesgado atribuir en exclusiva el carácter moderado del SOMA a la imitación de lo visto en Pas-de-Calais, ya que ni él cuando llega a Francia era un revolucionario ni la tendencia del SOMA en este aspecto difiere apenas de la desplegada por la UGT, en la que el sindicato asturiano se integrará muy pronto $^{30}$. Por tanto, cabe limitarse a señalar el hecho y apuntarlo como una más de las fuentes en las que bebe el sindicalista langreano.

Se suele citar erróneamente una supuesta influencia guesdista en el sindicato de Pas-de-Calais que habría servido como modelo para el SOMA ${ }^{31}$. Llaneza

${ }_{24}$ El Minero de la Hulla, 5 (diciembre 1914), pág. 4.

${ }^{25}$ LlaneZa ZAPICO, Manuel, «Evitemos el peligro», El Minero de la Hulla, 15 (octubre 1915), págs. 1-3.

${ }^{26}$ El Socialista, 25-1-1931; SABOrit, Asturias..., págs. 156; Pérez LedeSMa, El obrero..., págs. 242-243; SHubert, Hacia..., pág. 141 y SAÑa, Heleno, Líderes obreros: biografías, Bilbao, Zero, 1974, pág. 137.

${ }_{27}$ El Minero de la Hulla, 4 (nov. 1914), pág. 2, cit. en Moradiellos, El Sindicato..., pág. 43.

${ }_{28}$ PÉReZ Ledesma, El obrero..., pág. 242.

${ }^{29}$ LlaneZa ZAPICO, Manuel, «Ventajas de la organización», La Aurora Social, noviembre 1908, recogido en LLANEZA, Escritos..., págs. 67-70.

30 Moradiellos, El Sindicato..., pág. 45.

31 El equívoco procede, aparentemente, de la obra de SABORIT, Asturias..., pág. 156, de donde se propaga a la de RuIZ GonZÁlez, El movimiento...; la de SAÑA, Líderes..., pág. 137; la de MORADIELlos, El Sindicato..., pág. 156 y otras aún más recientes, como el artículo de GómEZ 
se inspiró en la Chambre Syndicale du Pas-de-Calais, popularmente conocida como Vieux Syndicat (VS), fundada en 1889 y que era ampliamente hegemónica en dicha cuenca en la época. Era un sindicato centralizado, reformista y

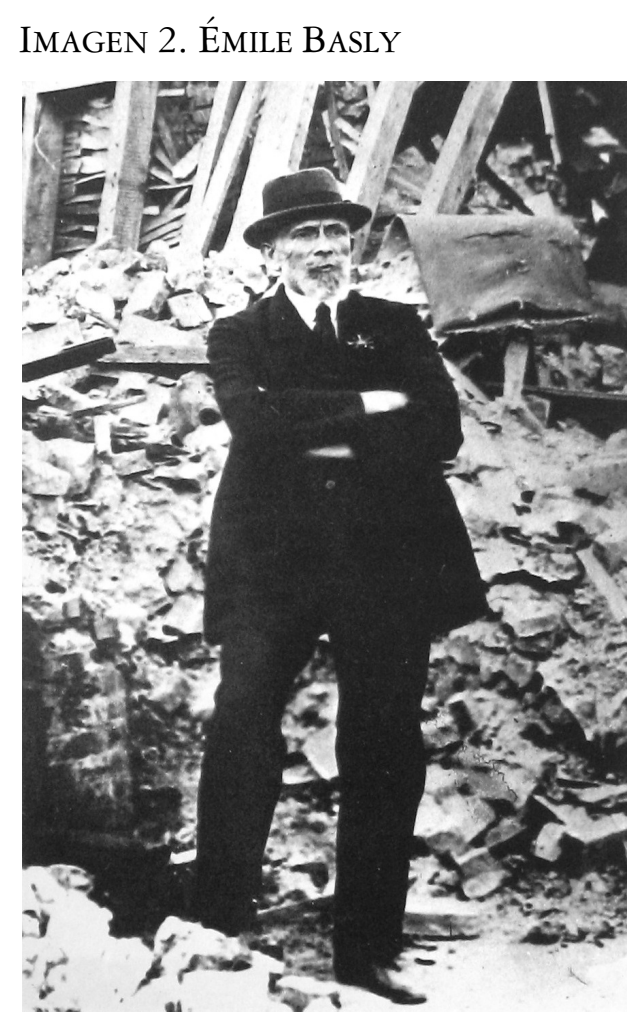

Émile Basly, líder del Vieux Syndicat y alcalde de Lens, en abril de 1918 entre las ruinas de su ciudad, totalmente arrasada durante la Gran Guerra. Extraído de LE MANER, «Un pionnier...", pág. 48. Collection La Voix du Nord.

con un líder carismático: Émile Basly, que fue también diputado y alcalde de Lens, la ciudad más importante del distrito minero; por lo que las analogías con el Llaneza diputado y alcalde de Mieres son inevitables ${ }^{32}$. La personalidad

Riestra, María Oliva, «Políticas públicas y obras sociales de Manuel Llaneza en Mieres», en: Almunia Amann, Joaquín et al., Apuntes de historia. FSA, 1901-2001, Oviedo, Fundación José Barreiro, 1999, pág. 139.

32 Sobre la figura y la obra de Basly, que podríamos considerar más un republicano de izquierda que un socialista y que ante todo se mantuvo siempre fiel a su amigo Millerand, resulta 
de Basly es tan destacada que llama la atención de sus coetáneos poderosamente, en tanto que minero huérfano autodidacta que encabeza la lucha de sus camaradas. De hecho, su participación en la huelga de Anzin de 1884 servirá a Émile Zola como inspiración no para uno, sino dos personajes de Germinal: Lantier, el cabecilla, y Rasseneur, el tabernero ${ }^{33}$.

De hecho, la organización influenciada por los partidarios de Jules Guesde y Paul Lafargue — el yerno de Marx — era la Fédération Syndicale des Mineurs du Pas-de-Calais, conocida coloquialmente como Jeune Syndicat (JS). Fundada en 1903, tenía un inequívoco propósito revolucionario y una estructura muy descentralizada y, por tanto, nada tenía que ver con el SOMA ${ }^{34}$. De hecho, el JS nació como respuesta a la laxitud del VS 35 , denunciada por el ala más radical del socialismo francés, que acababa de unificarse en el Parti Socialiste de France en 1900 y estaba fuertemente implantada en la región Nord - Pas-de-Calais gracias a los guesdistas del POF (Parti Ouvrier Français). Éstos, con ayuda de elementos anarquistas, trataron de presentar batalla también en el terreno sindical fundando el JS, que pareció poder amenazar la supremacía del VS entre 1900 y $1906^{36}$, año del terrible accidente de Courrières, en el que murieron más de mil mineros y que provocó una ola de indignación ante las responsabilidades de la empresa que el JS supo encabezar durante un cierto tiempo. Sin embargo, en la época en la que Llaneza lo conoció languidecía ya a la sombra de su competidor ${ }^{37}$, aunque el langreano aún fue testigo de refriegas mortales

imprescindible la visión de LE MANER, Yves, «Un pionnier du syndicalisme réformiste: Émile Basly (1854-1928), «Le Tsar de Lens»», Gauheria, 25 (1992). También el trabajo inédito de Michel, Joël, Emile Basly (1854-1928). Sur le syndicalisme des mineurs, Maîtrise, Université Lille III, 1972. Asimismo, la enciclopédica tesis de este último sobre el movimiento obrero entre los mineros de Europa occidental es de gran interés para conocer el caso concreto de Pas-de-Calais (vid. MiCHEL, Joël, Le mouvement ouvrier chez les mineurs d'Europe occidentale (Grande-Bretagne, Belgique, France, Allemagne): étude comparative des années 1880 à 1914, Doctorat d'État en Histoire Contemporaine, Univ. Lyon 2, 1987).

33 LE MANER, «Un pionnier...», pág. 41. Su atractivo se basaba en su carácter práctico, ya que siempre hablaba de logros concretos, y su cercanía a los mineros, a los que podía dirigirse en el dialecto local, como indica Michel, Émile Basly..., pág. 11.

${ }^{34}$ JULliard, Jacques, "Jeune et vieux syndicat chez les mineurs du Pas-de-Calais», Le Mouvement Social, 47 (1964), pág. 270 ; COOPER-RICHET, Diana, La Fédération Nationale des Mineurs. Contribution à l'bistoire du syndicalisme français avant 1914, Thèse soutenue à l'Université Paris I, 1976, pág. 269.

35 En particular el denuedo con el que, con frecuencia, se aplicaba Basly a la tarea de reventar huelgas. MiCHEL, Joël, «Les débuts de la SFIO dans le bassin houiller du Pas-de-Calais: 19051914», Revue du Nord, 221 (1974), pág. 159. En ocasiones, llegaba incluso a pedir discretamente a la prefectura que enviara gendarmes y soldados, como señala LE MANER, «Un pionnier...», pág. 44. Sobre los orígenes del JS, MiCHEL, Le mouvement..., pág. 2080-2081.

${ }^{36}$ Entre 1900 y 1906 el VS intentó esconder un importante descenso en su militancia, según COOPER-RicheT, La Fédération..., pág. 246. Parecía que la nueva generación se aproximaba a los postulados más revolucionarios de los guesdistas. MicHEL, Le mouvement ..., pág. 2038.

37 Tanto languideció que llegó a la práctica desaparición en 1912, cuando sólo unos cien fieles seguían a su líder, Benoît Broutchoux, según CoOPER-Richet, La Fédération..., pág. 245, y 
en Liévin entre partidarios de ambos sindicatos ${ }^{38}$. En cualquier caso, Basly fustigaba todavía a sus rivales a la menor ocasión:

Debemos felicitarnos por estas críticas, que nos permiten oponer a estos extractores de quintaesencia nuestro método incomparablemente más provechoso para los trabajadores mineros.

Lo que provoca la ironía y los desdeños de los negociantes de motines: cajas de pensiones y de socorros, ley de ocho horas, delegados mineros, Convenciones de Arras, es para nosotros motivo de orgullo. Que los anarquistas tengan el valor de pedir a los mineros el abandono voluntario de estas reformas. Serán bien recibidos ${ }^{39}$.

La aludida confusión en torno a la paternidad ideológica de los dos sindicatos franceses puede venir dada por un rasgo que Saborit menciona, relativo a la ausencia en ellos de «antagonismo entre la acción política y la acción sindical» ${ }^{40}$. En efecto, para Guesde era necesario combinar política y sindicalismo - lo cual tampoco constituía una terrible originalidad-, pero con la supremacía de aquella, justo al revés que en el caso del VS y del SOMA ${ }^{41}$, que tenían una proyección política autónoma a costa de sus respectivos partidos, como bien testimonian las carreras de Llaneza y Basly, especialmente cuando este último utilizaba el sindicato como agencia electoral en época de campaña ${ }^{42}$. De todas formas, ni la identidad de las luchas sindical y política era entendida de la misma manera ni esto puede llevar en ningún caso a afirmar que los sindica-

MiCHEL, Le mouvement..., pág. 2051. A pesar de la pérdida de importancia del JS desde 1906, las luchas entre ambas organizaciones son constantes y las alusiones en la prensa próxima a Basly casi diarias, ya sea regocijándose de las disensiones internas del vecino (BASLY, Émile, «Justice immanente», Le Réveil du Nord, 10-1-1909) o de su exclusión de la CGT tras la entrada en la misma del VS («Le syndicat Broutchoux exclu de la CGT. La fin du broutchoutisme», Le Réveil du Nord, 17-4-1909). En ocasiones, incluso, señalando enfrentamientos callejeros entre miembros de ambos sindicatos (Le Réveil du Nord, 19-2-1908). Para conocer la pugna entre Viejo y Joven Sindicato, además de las obras citadas más arriba, es de interés la de EvRARD, Raoul, «Dans le Nord - Pas-deCalais de 1898 à 1914», Cabiers de l'Institut d'Histoire Sociale Minière, 17 (1999).

${ }^{38}$ La Voix du Mineur, 16-5-1908, págs. 1-2.

39 BASLY, Émile, «Les deux méthodes», Le Réveil du Nord, 31-1-1909. Traducción del autor (TA). Artículos en esta línea, considerando positiva la acción reformista y vacía e infructuosa la retórica de los revolucionarios, son constantes (v.g., BASLY, Émile, «De l'action», 23-3-1909; FERDY, C. «Pour aboutir», 22-7-1909; MASSE, D., «Le contrat collectif de travail», 30-9-1909; BASLY, É., «L'action ouvrière», 24-10-1909; BASLY, É., «La bonne méthode», 23-11-1909; BASLY, É., «Reformistes et revolutionnaires», 5-7-1910...).

40 SABORIT, Asturias..., pág. 156.

${ }^{41}$ De hecho, el VS era muy celoso de cualquier injerencia y mucho más fuerte que el partido. MiCHEL, «Les débuts...», pág. 161 ; COOPER-RiCHET, La Fédération ..., págs. 433-434.

42 Michel, Émile Basly..., págs. 73-74; COOPER-Richet, La Fédération..., pág. 434 ; Moradiellos, El Sindicato..., pág. 46. Incluso se esfuerza en limitar la implantación en su feudo de la Section française de l'International ouvrière (SFIO), de la que es adherente desde el nacimiento de ésta. El resultado es una situación de trade-unionismo única en Francia: la política subordinada al sindicalismo. LE MANER, «Un pionnier...», pág. 46. 
tos de Pas-de-Calais estaban inspirados por Guesde. Si acaso, la organización minoritaria, que además entra pronto en la órbita anarquista para terminar extinguiéndose al poco y que de ninguna manera pudo servir de inspiración a Llaneza ${ }^{43}$.

\section{LO QUE NO SE HA ESCRITO SOBRE LA INFLUENCIA DEL VIEUX SYNDICAT EN LLANEZA}

Como se mencionaba anteriormente, es habitual aludir a la importancia de la experiencia francesa de Llaneza sin hacer explícito en qué se sustancia o, a lo sumo, citando el par de rasgos que acaban de esbozarse. Sin embargo, un pequeño acercamiento a la historia del VS revela nuevos e importantes elementos que lo emparentan con el SOMA. Quizá una de las primeras cosas que aprendió el langreano fue la importancia de la coyuntura en la acción sindical, dado que precisamente se encontraba trabajando fuera de su país por el fracaso de una huelga debido fundamentalmente a su inoportunidad, además de a la debilidad organizativa de las estructuras sindicales. En Pas-de-Calais descubrió que los mineros europeos tenían ya una gran experiencia en la precepción de la importancia de este asunto y buscaban argumentos en la situación del mercado y los beneficios de las compañías a la hora de negociar con los patronos, arte en el que Basly era un maestro. Llaneza y su sindicato cultivarían esta habilidad como alumnos aventajados, calculando con todo detalle y precisión los recursos y las debilidades de los trabajadores y de los patronos antes de plantear cualquier reivindicación y, más aún, un conflicto ${ }^{44}$. Un ejemplo paradigmático es la advertencia que el líder langreano hacía en 1915:

A la terminación de la guerra nuestros patronos dispondrán de más reservas que tenían en 1911, y ayudados quizá por las circunstancias, ¿no ha de ser una profecía el pensar que traten de dar la batalla a nuestra organización? ${ }^{45}$.

Otra enseñanza importante, que podríamos considerar más o menos directamente derivada de la anterior, fue la necesidad de disciplina. Basly entendía el sindicato como un arma, un argumento negociador que no debía ser em-

43 Por lo que respecta a los guesdistas, se ha señalado que son creadores de una cultura política que marca una continuidad social, por la vía del antibaslysmo fundamentalmente, hasta entroncar con el comunismo cuando éste aparece. Así lo avalaría la implantación geográfica, que en muchos casos es coincidente para POF, JS y PCF, como en las municipalidades de Avion, Méricourt, Drocourt... Vid. LECOMTE, André, La SFIO à Lens de 1928 à 1940, Mémoire de Mâ̂trise sous la direction de M. Hilaire, Université Lille III, 1976, pág. 173; RIBAUCOURT, Guy, Broutchoux, la Fédération syndicale des ouvriers mineurs du Pas-de-Calais et L'Action Syndicale (1902-1914), Mémoire de Maîtrise sous la direction de M. Gillet, Université Lille III, 1978, pág. 196.

${ }_{4}$ Para el caso francés, MiCHel, Émile Basly..., pág. 12. Sobre la aplicación de estos principios en Asturias, PÉrez Ledesma, El obrero..., pág. 244 y Moradiellos, El Sindicato..., pág. 44.

45 LlaneZa Zapico, Manuel, "Creemos medios y almas socialistas», El Minero de la Hulla, 1712-1915, recogido en: LlanEZA, Manuel, Escritos..., pág. 79. 
pleado a la ligera para no ponerlo en peligro. El VS era algo que se mostraba mucho más de lo que se utilizaba, característica que heredará el SOMA ${ }^{46}$. De la reflexión según la cual hacer uso de la capacidad movilizadora de la organización puede convertirse en una amenaza para su supervivencia se infiere que es importante contar con un gran número de afiliados; pero es igualmente vital que éstos sean disciplinados y que cada paso sea dado de forma unitaria y, sobre todo, en el momento preciso para evitar descalabros ${ }^{47}$. Organizaciones de masas por tanto, pero de masas obedientes.

¿Es posible que obreros pertenecientes a una organización sindical se pongan en huelga por su propia iniciativa, antes de haber agotado todos los medios de conciliación, y sobre todo antes de cualquier decisión de la Sección o del Consejo de Administración del Sindicato? Yo digo que no ${ }^{48}$.

Eso las alejaba de otras que, como el JS, tenían unos afiliados y simpatizantes menguados en número pero muy activos, con bastante más iniciativa.

El instinto de supervivencia institucional tenía también un reflejo en el manejo de los fondos. Se ha mencionado ya que la constitución de una caja central de resistencia bien nutrida era uno de los puntos fuertes más característicos de este tipo de sindicato. Paradójicamente, la predisposición a su empleo era nula, aunque esto le valiera derrotas en huelgas que eran vencidas por agotamiento económico de los trabajadores mientras el dinero del sindicato criaba telarañas ${ }^{49}$. Semejante actitud no era en realidad más que una prolongación de su conservadurismo a la hora de considerar la posibilidad de desencadenar un conflicto. La causa era, ni más ni menos, el miedo a ver destruida su obra; de

${ }^{46}$ Los estatutos del SOMA establecían que antes de llegar a la huelga debía negociar la sección del sindicato afectada con la empresa, después el Comité Ejecutivo intentaría de nuevo satisfacer la reclamación negociando con el patrón y finalmente se convocaría un Congreso extraordinario para decidir qué hacer, necesitando una mayoría de dos tercios para poder aprobar la huelga. Cit. en MORADIELLOS, El Sindicato..., pág. 45.

${ }^{47}$ MiCHEL, Émile Basly..., pág. 64. El VS era entendido como mero grupo de presión, según COOPER-RicheT, Le peuple de la nuit. Mines et mineurs en France XIXe-XXe siècles, Paris, 2002, pág. 244. Como elemento homogenizador de la opinión contaba con Le Réveil du Nord (El Despertador del Norte), diario editado en Lille por amigos republicanos radicales de Basly y de cuyo consejo editorial éste llegó a formar parte. Tenía gran difusión entre los mineros y, en la práctica, actuó como un periódico del sindicato. Sus detractores lo llamaban L'Endormeur du Nord (El Adormecedor del Norte).

48 BASLY, Émile, «Deux exemples», Le Réveil du Nord, 23-8-1910 (TA).

${ }_{49}$ Michel, Joël, Émile Basly..., págs. 65-66. En 1893 los huelguistas vuelven derrotados al trabajo mientras la caja del sindicato apenas había tocado los 200000 francos que atesoraba, según Le MANER, «Les grandes grèves minières du Pas-de-Calais», en: RebÉRIOUX, M. (dir.), Fourmies et les $1^{e r}$ mai, Paris, 1994, pág. 293. Sin embargo, Basly defendía que los afiliados pagaran cuotas gravosas, en contra de la opinión de los revolucionarios, porque aunque fuera remiso a emplearla pensaba que el principal activo negociador del VS era su caja de resistencia. BASLY, Émile, «De l'action», Le Réveil du Nord, 23-3-1909. Lo mismo sucede en el SOMA. CallejA, José, «¿Debemos aumentar la cuota?», El Minero de la Hulla, 40 (noviembre 1917), pág. 7. 
ahí que por lo general mostrara un gran interés por la conciliación y tratara de desactivar las huelgas recomendando consagrarse al fortalecimiento de la organización, garante de todas las conquistas.

El proletariado no necesita nuevas sangrías. Las que se le han infligido bastan. Está decidido a llevar a cabo el arduo trabajo de organización que le liberará en lugar de arrojarse una vez más bajo los golpes de la burguesía furiosa ${ }^{50}$.

Y ello a pesar de que en 1906 había aumentado las cuotas de cincuenta céntimos a dos francos mensuales precisamente para crear una caja de resistencia y paro ${ }^{51}$. Normalmente los afiliados, en tanto disfrutaban de ventajas salariales y sociales desconocidas en otras corporaciones gracias a los convenios colectivos pactados desde 1889 entre sindicato y patronal (Conventions d'Arras), se manifestaron bastante conformes con este principio de prudencia porque temían que una huelga dispusiera a la patronal a no renovar dichos precoces acuer$\operatorname{dos}^{52}$. De todas formas, en ocasiones el moderantismo del sindicato ante la acción directa se veía sobrepasado por el empuje de unas bases que siempre estaban más dispuestas a la lucha que sus dirigentes, hasta el punto de forzarlos en algunos casos a convocar huelgas para no perder el control de la situación y poder reconducirla posteriormente. Este rasgo, presente también en el sindicato asturiano ${ }^{53}$, lógicamente se acentúa en épocas de dificultades especiales. Por ejemplo, durante la dictadura franquista el SOMA, como en general el movimiento socialista, se aplicó fundamentalmente a preservar sus estructuras en lugar de tratar de combatir al régimen, dejando así de ser un medio para convertirse en un fin en sí mismo ${ }^{54}$.

Sin embargo, en sus inicios —entre 1911 y 1913 - el SOMA mostró una gran combatividad, obligado por la intransigencia de las empresas, para conseguir ser reconocido como interlocutor ${ }^{55}$. El último cuatrimestre de 1910 fue de intensa propaganda con vistas a la creación del sindicato ${ }^{56}$, que apenas comenzado 1911 iniciaba la primera de estas cruciales huelgas fundacionales a causa

50 BASLY, Émile, «Reformistes et revolutionnaires», Le Réveil du Nord, 5-7-1910 (TA).

${ }^{51}$ Comité Central de Houillères de France, Circulaire 3614, La situation financière des syndicats d'ouvriers mineurs de France, 14 juin 1908.

52 MiChel, Émile Basly..., pág. 12; COOPER-RiChet, La Fédération..., pág. 434; KourChid, Olivier et TREMPe, Rolande (dirs.), Cent ans de conventions collectives: Arras, 1891-1991: actes du colloque d'Arras, 21-22 novembre 1991, Villeneuve d'Ascq, Univ. Lille 3, 1994.

53 SHUbert, Hacia..., pág. 161; Moradiellos, El Sindicato..., pág. 67.

${ }_{54}$ Respecto a la estrategia socialista durante la dictadura, véase la reciente aportación de VEGA GARCíA, Rubén, «Entre la derrota y la continuidad generacional. Continuidad y ruptura en la protesta social», en: ABDÓN MATEOS (ed.), La España de los cincuenta, Madrid, Eneida, 2008.

55 De LA Fuente, José, "Origen y actuación de nuestro sindicato», El Minero de la Hulla, 39 (octubre 1917), pág. 6.

56 Véase, por ejemplo, El Noroeste, 17-9-1910, pág. 1, 5-10-1910, pág. 3, 29-10-1910, pág. 3 o 27-12-1910, pág. 4. 
del despido de veintisiete obreros de Fábrica de Mieres participantes en los actos del primero de mayo, símbolo de la oposición de la empresa a toda organización de sus trabajadores. El paro fue un éxito y la compañía se vio obligada a reconocer su derrota ${ }^{57}$. El resultado fue inmediato y el sindicato alcanzó, a mediados de ese año, los mil ochocientos afiliados ${ }^{58}$. Esta victoria puso en guardia a los patronos, que se mostraron más duros si cabe a partir de entonces, por lo que el SOMA tuvo que seguir enlazando conflictos victoriosos, como el de Hulleras del Turón, que trajo la primera huelga general del sector ${ }^{59}$. En penúltimo lugar, fue la Hullera Española del marqués de Comillas la que quiso echarle un pulso que perdió igualmente en una huelga de dieciocho días con un pequeño rebrote meses después ${ }^{60}$.

Vencidas tres de las más grandes, poderosas e inflexibles compañías, los dirigentes del sindicato pensaban que la lucha por el reconocimiento no había terminado e instaban a no confiarse ${ }^{61}$. No se equivocaban, porque la mina de Arnao de la Real Compañía Asturiana de Minas iba a estar casi un año en una huelga alentada y sostenida por el SOMA, pero fallida a causa de la cerrazón del director, que prefirió sufrir grandes pérdidas económicas y el riesgo de comprometer el abastecimiento de la fábrica de zinc anexa antes que sentarse siquiera a negociar ${ }^{62}$. Semejante muestra de integrismo, sin duda producto del ambiente de omnipotencia en el que se habían desenvuelto las empresas hasta entonces, se antoja aún mayor sabiendo que el SOMA renunció de forma temprana a una parte importante de las reivindicaciones, limitándose a solicitar la readmisión del despedido ${ }^{63}$. Desde el principio el sindicato trató de borrar este fracaso de la memoria, seguramente porque se consideraba que el proselitismo se vería amenazado si los mineros empezaban a pensar que, pese a los nuevos métodos organizativos, las victorias iniciales habían sido fruto de la casualidad. Por fortuna para el SOMA, este tipo de conflicto no se reprodujo nunca porque era también sumamente indeseable para las empresas. Por eso su afianzamiento y expansión continuaron hasta convertirlo en la organización socialista más

57 El Noroeste, 1-5-1914, pág. 8; LlaneZA ZAPICO, «Veinte años...», pág. 1 y DE LA FUENTE, «Origen...», pág. 7. Sindicato de los Obreros Mineros Asturianos, Memoria y estado de cuentas durante el año de 1911, pág. 1.

58 El Noroeste, 24-8-1911, pág. 3.

59 LlaneZA ZAPICO, «Veinte años...», pág. 1 y El Noroeste, 11-9-1911, pág. 3, 12-9-1911, pág. 1 y 15-9-1911, pág. 3. También en un artículo retrospectivo en El Noroeste, 1-5-1914, pág. 8. El informe anual del SOMA deja claro que lo que pretendía ventilar la empresa era la propia existencia del sindicato. SOMA, Memoria y estado de cuentas durante el año de 1911, pág. 2.

60 El Noroeste, 24-5-1912, pág. 1, 6-6-1912, pág. 1, 7-6-1912, pág. 4, 27-9-1912, pág. 1 y 1 10-1912, pág. 4. En medio de estas luchas Llaneza perdía a su padre, a mediados de 1912. El Noroeste, 12-6-1912, pág. 4.

${ }^{61}$ El Noroeste, 9-7-1912, pág. 4.

62 El desarrollo de la huelga se puede seguir en la correspondencia del director, Pedro Pascual de Uhagón, Archivo Histórico de Asturiana de Zinc, L 1004.

${ }^{63}$ El Noroeste, 7-11-1912, pág. 4 y 17-11-1912, pág. 1. 
poderosa del país. Terminado este período inicial marcado por estas cuatro grandes huelgas, el sindicato entró en la dinámica moderada y prudente que le caracterizaría en el futuro, porque incluso las luchas que permitieron su consolidación definitiva con conquistas durante los años de la Gran Guerra fueron de un carácter muy diferente ${ }^{64}$. A partir de entonces, según expresión del propio Llaneza, «terminaron las huelgas de carácter violento, y si hasta 1917 hubo huelgas, éstas fueron tranquilas y siempre victoriosas» ${ }^{65}$.

\section{IMAGEN 3. MANUEL LLANEZA Y ANTO- NIO F. CIENFUEGOS}

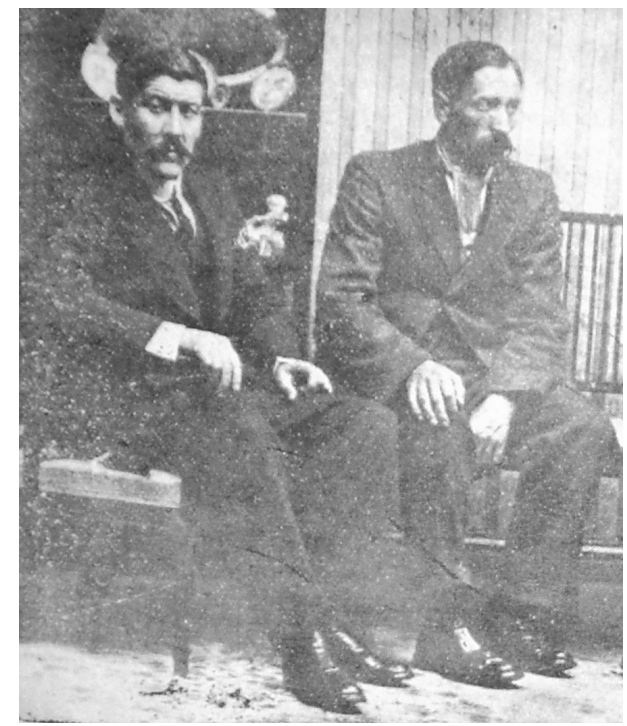

Manuel Llaneza y Antonio F. Cienguegos, secretario y presidente del SOMA, en el despacho de Canalejas en 1912, tras haber logrado un aumento de cincuenta céntimos en los salarios. Extraído de El Minero de la Hulla, 12 (Tercera Época) (diciembre 1929), pág. 2.

64 Véanse como ejemplo los acuerdos con la patronal en 1915, en El Noroeste, 7-6-1915, pág. 4. En 1914 se logró el salario mínimo, una de las reivindicaciones más queridas de estos primeros tiempos. «Hablando con Manuel Llaneza», El Minero de la Hulla, 32 (marzo 1917), pág. 3.

65 Manuel LlaneZA ZAPico, «Veinte años de lucha», El Minero de la Hulla, 12 (Tercera Época) (diciembre 1929), pág. 2. Llaneza hace terminar este período especialmente belicoso del inicio en 1912 en lugar de 1913, pero esto se explica porque en este último año registró la única derrota, contra la Real Compañía Asturiana de Minas. Por ese motivo, como se ha señalado ya, este conflicto fue borrado de los relatos oficiales sobre los orígenes de la organización, como el de De la Fuente, este mismo o incluso la memoria de actividades del sindicato en 1913. 
Dentro de esta lógica moderada, los acuerdos de Arras fueron un modelo para la aplicación gradual de instrumentos de negociación similares en Asturias, dado que desde 1913 existió una comisión mixta para tratar los problemas laborales, inicialmente para debatir la citada pretensión del SOMA de instaurar un salario mínimo ${ }^{66}$. Nótese que, vencidas por fin las resistencias de las empresas a tratar con el sindicato, a partir de esta época se empiezan a conquistar avances concretos. La ascendencia del sistema de conciliación para evitar huelgas es de nuevo claramente francesa, porque allí se adoptaron pronto los comités mixtos de arbitraje. La actitud favorable del VS ante estos proyectos de Millerand, puestos en marcha y debatidos estando Llaneza en el país, se puede constatar en artículos aparecidos en Le Réveil du Nord los días 25-3-1908, 18-51908, 20-2-1909 (en este caso una conferencia del mismo Millerand titulada «L'arbitrage dans les grèves»), 6-5-1909 (de Dubief, vicepresidente del Congreso de los Diputados), 18-7-1909, 4-8-1909 (sobre el arbitraje en el Reino Unido)... El propio Basly expresó su opinión en tres artículos, aparecidos el 112-1909, 7-12-1909 y 14-6-1910:

La idea de una solución amistosa de las diferencias entre empleadores y empleados hace cada vez más progresos en todos los medios. Sin duda, los derviches del anarquismo la encuentran comprometedora para quienes la defienden, pero esto es sólo un detalle sin importancia ${ }^{67}$.

No por casualidad encontramos en Llaneza el mismo tipo de propósito:

La armonía entre el capital y el trabajo no podrá existir nunca (...); pero siguiendo la línea de conducta ahora indicada, limaremos asperezas y evitaremos las luchas continuas que origina la intransigencia patronal, y que nunca traían beneficios positivos [sic] para ninguno de los dos contendientes ${ }^{68}$.

La querencia del SOMA por el diálogo institucionalizado y el arbitraje estatal hará que en su momento se encuentre a sus anchas en los «comités paritarios», artefacto corporativo de la dictadura de Primo de Rivera con representación patronal, obrera y gubernamental y el objetivo de erradicar los conflictos callejeros $^{69}$. El jerezano se congraciaba con las empresas protegiendo el carbón asturiano y a cambio éstas aceptaban negociación y concesiones a los obreros,

${ }^{66}$ El Noroeste, 2-7-1913, pág. 2, 18-8-1913, pág. 3 y 11-9-1913, pág. 1. Llaneza aprovechó el gran revuelo organizado por la contratación de quinientos mineros asturianos para trabajar en las minas de Courrières para promocionar la idea del salario mínimo aduciendo que si existiera esa seguridad en España como existía ya en Francia estos trabajadores se sentirían menos predispuestos a la emigración. LlaneZA ZAPICO, Manuel, «Los mineros asturianos. Ellos y nosotros. Para El Carbayón», El Noroeste, 25-7-1913, pág. 4.

67 BASLY, Émile, «Comités miniers permanents», Le Réveil du Nord, 1-12-1909 (TA).

${ }^{68}$ LLANEZA ZAPICO, «Mirando al porvenir...», pág. 75.

69 Moradiellos, El Sindicato..., pág. 116. 
representados necesariamente en los comités por un SOMA colaboracionista que era el único sindicato tolerado. Todos ganaban: las empresas conseguían ayuda, el sindicato aumentaba su influencia y el dictador compraba paz social.

El VS tenía una acentuada tendencia, agrandada si cabe por la actividad parlamentaria de su líder desde antes incluso de la fundación del sindicato, a confiar en la legislación para obtener avances graduales y sin demasiados riesgos ${ }^{70}$.

El Sindicato no es un arma de combate contra las compañías y el capital, y si algunos le atribuyen este carácter están pisoteando las leyes votadas por la República. Pero vosotros tenéis ahora un diputado minero que juró en lo alto de la tribuna reclamar las modificaciones necesarias a las leyes votadas a favor de los obreros y exigir su aplicación ${ }^{71}$.

El paradigma de esta inclinación a obtener mejoras con el concurso de los legisladores será sin duda el apoyo de los mineros a las reformas graduales de Millerand, socialista muy próximo a Basly que entra en el gabinete WaldeckRousseau en 1899 -sintomáticamente, suscitando las iras de quienes, como Guesde, consideraban indeseable esta colaboración con partidos burgueses_ ${ }^{72}$. Hubo reivindicaciones en torno a la jubilación, el descanso semanal, el derecho a vacaciones... ${ }^{73}$. En especial la reducción de la jornada a ocho horas fue objeto de los desvelos del VS durante mucho tiempo, hasta que por fin fue medida efectiva desde el 1 de enero de 1910, momento a partir del cual se convirtió en vigilante de su cumplimiento ${ }^{74}$, lo que le llevó a sostener huelgas como la que Llaneza conoció en su empresa justo antes de regresar a Asturias ${ }^{75}$. Éste apren-

70 MiCHel, Émile Basly..., pág. 11.

71 BASLY, Émile, 12-4-1891, cit. en: MiCHEL, Émile Basly..., pág. 60 (TA).

72 CoOper-Richet, La Fédération..., pág. 435. Del millerandismo de Basly, MiCHEL, «Les débuts...», pág. 155. El tiempo terminaría por dar la razón a los guesdistas, ya que Millerand se integró en la derecha con la Gran Guerra como catalizador, llegando a ser presidente del gobierno en 1920 y de la República entre ese año y 1924. Hay que matizar, en cualquier caso, que la derecha francesa se diferencia bastante de la española sociológica y doctrinalmente a causa de la herencia revolucionaria de la idea republicana de ciudadanía. Véase LAMBERT, Frédéric, Introduction à l’histoire des idées politiques. $19^{\text {ème }}-20^{\text {ème }}$ siècles, Paris, Armand Colin, 2001.

73 Noticia sobre el congreso del sindicato en La Voix du Mineur, 25-4-1908. La campaña por las ocho horas, cuyo proyecto había sido depositado por Basly en el Senado y allí se encontraba bloqueado, era prácticamente ininterrumpida en este periódico. Fundado el año anterior, era el órgano oficial del sindicato y tenía periodicidad semanal. Sin embargo, Le Réveil du Nord continuó ejerciendo esa tarea en paralelo y de forma oficiosa, seguramente porque de lo publicado en él Basly tenía que dar menos explicaciones y además resultaba más ágil por ser diario. También se habla de las citadas reivindicaciones en BASLY, Émile, «Les mineurs et les pouvoirs publics», Le Réveil du Nord, 20-5-1909, y BASLY, Émile, «Le chômage», Le Réveil du Nord, 21-6-1910

74 Sobre la campaña por su obtención, ver, v.g. Le Réveil du Nord, 14-5-1909, 20-5-1909 y 137-1909. De las medidas para que se cumpliera, BASLY, Émile, «La loi de huit heures dans les mines», Le Réveil du Nord, 11-1-1910.

75 La Voix du Mineur, 6-8-1910, pág. 2. 
dió muy bien la lección sobre la utilidad de la legislación porque consiguió que, con efecto 1 de enero de 1920, los mineros españoles fueran los primeros del mundo en lograr una jornada de siete horas «de bocamina a bocamina» ${ }^{76}$. El SOMA siempre defendió que la reducción de la jornada debían arrancársela al gobierno y no a las compañías, para que fuera realmente efectiva ${ }^{77}$. La fe en el Parlamento explica a su vez la concepción limitada y desprovista de cualquier veleidad revolucionaria que los baslycots —algo no tan común a principios del siglo XX - tenían de la huelga general, que se interpretaba como un instrumento de presión sobre las instituciones llamado a manejarse con templanza ${ }^{78}$. Esto, obviamente, les ubicaba también en las antípodas del JS ${ }^{79}$.

El SOMA adoptó desde el primer momento esta forma de entender las relaciones con los poderes públicos, reclamando en 1912 la promulgación de un Código Minero para regular las condiciones de trabajo en las minas. Pronto se sumó la creación de un impuesto sobre el carbón extraído para financiar un orfanato minero que vería la luz en 1929. Igualmente, se reclamó la eternamente debatida protección arancelaria de la hulla y la instauración de un cuerpo de inspectores obreros que verificaran la seguridad de las instalaciones y el cumplimiento de las normativas ${ }^{80}$. En Francia, donde existía desde 1890, el inspector obrero se había convertido no sólo en un agente de seguridad de la mayor importancia, sino también en un crucial activo para el sindicato, ya que por la dotación económica que percibía era totalmente independiente de las compañías pero su labor inspectora le dejaba tiempo para tareas sindicales ${ }^{81}$. Como reconocía Basly en 1909: «Par les facilités, les loisirs que lui laisse sa fonction, le délégué est la plupart du temps un propagandiste du Syndicat ${ }^{82}$. En consecuencia, el VS intentaba permanentemente ampliar las funciones de estos delegados, como es el caso precisamente de 1908, durante la estancia de Llaneza ${ }^{83}$, que tuvo necesa-

76 Moradiellos, El Sindicato..., pág. 61.

77 Revista Industrial Minera Asturiana, 16-1-1919, pág. 21.

78 Alegatos contra el uso de la huelga general que hacían los anarquistas y los «socialistas anarquizantes» eran con frecuencia lanzados desde las páginas de Le Réveil du Nord. V.g., FOURNIERE, Eugène, «Grèves partielles et grève générale», Le Réveil du Nord, 14-3-1908.

79 CoOper-Richet, La Fédération..., pág. 433.

80 En resumen, una estrategia de conquistas parciales y consecutivas que ir asentando. SHUbert, Hacia..., págs. 154 y ss.; PÉrez LEDESMA, El obrero..., pág. 249-250. Sobre la protección arancelaria, LLANEZA ZAPICO, Manuel, «Una conferencia sobre la crisis hullera», Revista Industrial Minera Asturiana, 16-3-1921, recogido en: LlANEZA, Manuel, Escritos..., pág. 327.

${ }^{81}$ Los delegados mineros de seguridad e higiene son creados en Francia por la ley de 8 de julio de 1890, según Dubois, Guy, Histoire des mineurs du Nord - Pas-de-Calais... à l'usage de leurs petitsenfants, Lilliers, G. Dubois, 1996, pág. 83. De su importancia para el sindicato, MiCHEL, Le mouvement..., págs. 592-593.

82 BASLY, Émile, «Les délégués mineurs et les caisses de secours», Le Réveil du Nord, 24-1-1909.

83 Comité Central des Houillères de France, Circulaire 3621, Délégués mineurs. Rapport fait au nom de la Commission des mines chargée d'examiner le projet de loi sur les délégués mineurs, par M. Basly, député, 23 juin 1908. 
riamente que comprender la importancia de esta figura, porque además las investigaciones en torno a la catástrofe de Courrières estaban a diario en el candelero y a menudo delegados o el mismo Basly las comentaban en el periódi$\mathrm{CO}^{84}$. Nada tiene de extraño entonces que a su vuelta propusiera la instauración de esta figura en las minas asturianas criticando la ley de Policía Minera vigen$\mathrm{te}^{85}$, se mostrara disconforme cuando el proyecto de Código Minero contemplaba un sistema de elección que no privilegiaba al sindicato ${ }^{86}$ o compareciera ante una comisión parlamentaria ad hoc para defender el modelo francés ${ }^{87}$. Por supuesto, al lograr su acta de diputado en 1923 y como quiera que la cuestión seguía de actualidad, la llevó de nuevo al hemiciclo, lo que le valió severas críticas de los medios patronales, que habían temido desde el principio la instauración de los inspectores mineros como eventual caballo de Troya y habían hecho lo posible por eliminar del código los artículos 250 y 251, que eran los relativos a esta cuestión ${ }^{88}$.

El SOMA fue consciente también desde el principio de que una política asistencial propia era indispensable para disputar la fidelidad de los trabajadores a las compañías, que asentaban su hegemonía social en un entramado de instituciones paternalistas ${ }^{89}$. Por eso, libradas las primeras y acuciantes batallas y asentado el sindicato, en 1913 se inició todo un programa social que incluía cooperativas que sustituyeran a los economatos de empresa, casas del pueblo que hicieran lo propio con los centros recreativos patronales, escuelas y asociaciones mutualistas con el mismo fin y así sucesivamente ${ }^{90}$. Llaneza contempla-

${ }^{84}$ Algunos artículos de Basly sobre las consecuencias del accidente de Courrières de 1906 publicados en Le Réveil du Nord en los años en que Llaneza estuvo en Francia: 11-1-1908, 18-11908, 26-1-1908, 9-2-1908, 23-2-1908, 8-3-1908, 12-4-1908, 17-2-1909, 2-3-1909, 8-3-1909, $14-11-1909 \ldots$

${ }^{85}$ El Noroeste, 3-9-1911, pág. 3. «Legislación minera», El Minero de la Hulla, 14 (septiembre 1915), págs. 1-2. La campaña incluyó abundante información sobre el estado de la cuestión en otros países europeos, teniendo siempre el caso francés como ejemplo a seguir. Vid. «Inspección en las minas», El Minero de la Hulla, 3 (octubre 1914), págs. 11-12.

86 El Noroeste, 19-10-1912, pág. 3, 26-10-1912, pág. 4 y 28-10-1912, pág. 1.

87 El Noroeste, 6-11-1912, pág. 3.

88 «Los accidentes en las minas y los discursos del diputado socialista Sr. Llaneza», Revista Industrial Minera Asturiana, 1-8-1923, págs. 234-235; "El Código Minero», El Minero de la Hulla, 16, (noviembre 1915), págs. 1-2.

${ }^{89} \mathrm{La}$ obra imprescindible para una visión quirúrgica del paternalismo en la minería asturiana es la citada de Sierra ÁlvareZ, El obrero... Más reciente y con referencia a la implantación local y el control espacial de tres empresas diferentes, MUÑIZ SánCHEZ, Jorge, Del pozo a casa. Genealogías del paternalismo minero contemporáneo en Asturias, Gijón, Trea, 2007.

${ }^{90}$ Moradiellos, El Sindicato..., pág. 49; El Noroeste, 20-8-1912, pág. 4, 12-10-1913, pág. 4, 26-6-1915, pág. 4. La vocación asistencialista la retrataba claramente Llaneza cuando pedía, por ejemplo, «hacer del sindicato un Estado, dentro del cual (...) todos los obreros hallen (...) beneficios inmensos que sólo puedan disfrutar perteneciendo a él», LLANEZA ZAPICO, «Mirando al porvenir...», pág. 75; LlANEZA ZAPICO, Manuel, "A continuar la obra», El Minero de la Hulla, 12 (julio 1912), págs. 4-5. 
ba el sindicato como el centro de una red de organizaciones asistenciales ${ }^{91}$, cuyo objetivo era cortar paulatinamente todos los lazos extralaborales que ligaban al obrero con su empresa y le impedían actuar libremente. Dentro de este marco, fue un hito importante la creación del Orfanato Minero anteriormente citado. Esta conquista, una de las más queridas de Llaneza y pieza clave de la estrategia asistencial del SOMA, se materializó a finales de 1929 y supuso la creación de una «(...) institución benéfico-docente sometida a la jurisdicción del Ministerio de Fomento», teniendo como fuente de ingresos un canon de veinticinco céntimos pagado por las empresas por tonelada de carbón extraído ${ }^{92}$. Este importante logro testimonia la colaboración del SOMA con los intelectuales regeneracionistas como Ernesto Winter, que dirigirá el centro y lo diseñará inspirándose orgánicamente en el formato adoptado en los países industrializados y pedagógicamente en los postulados institucionistas ${ }^{93}$. Su fin era ocuparse de los huérfanos, «(...) acogiendo, alimentando, vistiendo, curando y educando (...)», según rezaba su reglamento ${ }^{94}$. Inmediatamente la nueva institución, regida por un patronato con tres representantes de la administración, tres de las empresas y otros tantos de los obreros $^{95}$, se erigió en un instrumento añadido de la hegemonía social del sindicato en la región. Desde el primer momento las elecciones de los representantes obreros en el patronato se convirtieron en una cita crucial en la que el SOMA se batía e intercambiaba todo tipo de acusaciones con sus rivales sindicales ${ }^{96}$. Como no podía ser de otro modo, ya en la primera convocatoria los candidatos del SOMA se impusieron con rotundidad. En 1930 Belarmino Tomás, Manuel Llaneza y Amador Fernández doblaron en votos a los candidatos comunistas y cuadruplicaron a los católicos ${ }^{97}$.

La sorda labor de zapa progresiva que la política asistencial del SOMA suponía para la red social de las empresas también la había llevado a cabo el VS, que cuando Llaneza lo conoció se dedicaba en particular a intentar democratizar el funcionamiento de las cajas de seguros, que hasta entonces y a pesar de las cotizaciones hechas por obreros, eran gestionadas de forma discrecional y por tanto siempre coactiva por las compañías ${ }^{98}$. En 1909 Basly se felicitaba de

${ }^{91}$ LLANEZA ZapiCO, Manuel, «Ante los grandes problemas. III. Sindicato profesional», El Minero de la Hulla, 27 (octubre 1916), págs. 1-2, y «Ante los grandes problemas. IV. Cooperativismo», El Minero de la Hulla, 28 (noviembre 1916), págs. 1-3.

92 Gaceta de Madrid, 29-12-1929.

93 TeRrón BAÑUelos, Aida, «¿Recoger y sembrar? La complejidad de la innovación educativa analizada en un contexto regional. El caso de Asturias», Revista de Educación, número extra (2007), págs. 140-141.

${ }_{94}$ El Noroeste, 3-1-1930, pág. 2.

95 Gaceta de Madrid, 29-12-1929.

${ }^{96}$ El Noroeste, 21-3-1930, pág. 5, 26-3-1930, pág. 4, 27-3-1930, pág. 3.

97 El Noroeste, 1-4-1930, pág. 1.

98 Desde la ley de 1894, los obreros entran en los órganos rectores de las cajas, pero frecuentemente las empresas se las ingenian para conseguir que sean elegidos candidatos dóciles y hacer un uso patrimonial de las mismas. TREMPÉ, Rolande, «Rôle et évolution de la loi de 1894», en: VV. 
que, por fin tras quince años de elecciones para delegados en las cajas de seguros — desde la aprobación de una ley ad hoc en 1894- la empresa más importante de la cuenca, la Société des Mines de Lens, no había presentado candidatos afines para competir con los del sindicato en la representación obrera en tal institución. "C'est l'indice que les caisses de secours échappent de plus en plus à la dictature des exploitants» ${ }^{99}$. En 1916, Llaneza decía que era necesario «ir arrancando a la clase patronal minera de Asturias las Cajas mutualistas que hoy ellas administran en defensa de sus propios intereses» ${ }^{100}$. De hecho, trabajando en Liévin había podido asistir a la toma de control de la caja de seguros de la empresa por parte del VS ${ }^{101}$. No hay que olvidar, en efecto, que el langreano trabajó para la Société Houillère de Liévin, que, aunque tenía fama de liberal ${ }^{102}$, contaba con no pocas instituciones paternalistas. Además de seguros y servicios médicos la empresa mantenía dispensarios y centros de fisioterapia, pediatras (ver imagen 4) e instituciones puericultoras como las gotas de leche ${ }^{103}$.

\section{IMAGEN 4. CONSULTA DE PEDIATRÍA DE LIÉVIN}

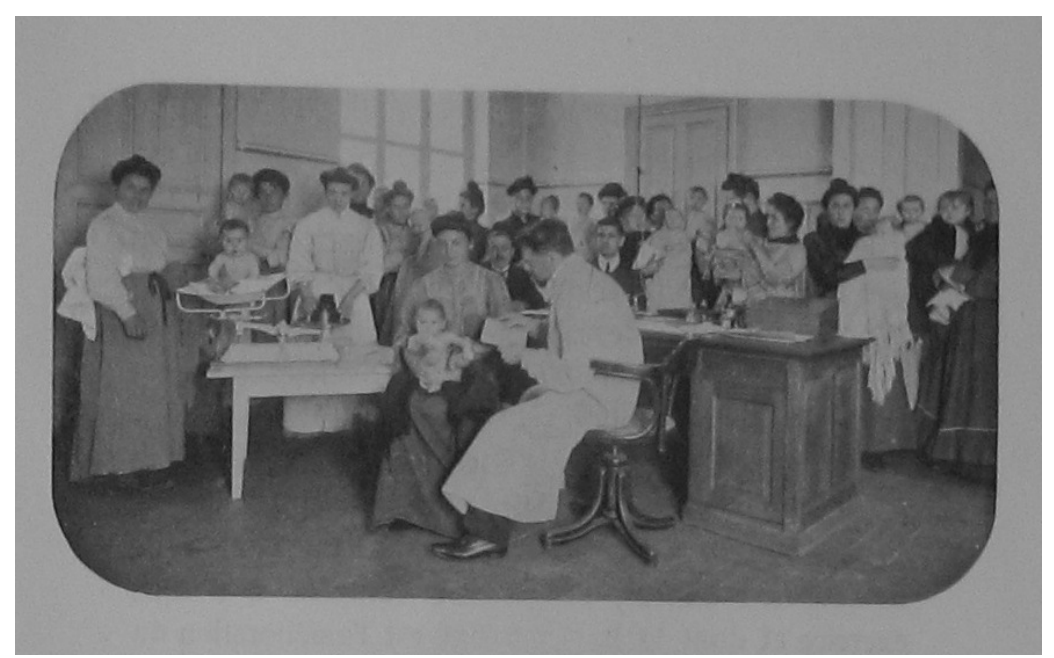

Consulta de pediatría de la Société Houillère de Liévin. Société Houillère de Liévin, Euvres Sociales. Expo Roubaix 1911, Douai, 1911, pág. 27.

AA., Santé et retraite des mineurs, un siècle et demi d'histoire, Paris, 1995, pág. 34; TREMPÉ, Rolande, «Rapide historique introductif», en: VV. AA., Santé et retraite..., págs. 5-7.

99 BASLY, Émile, «Les caisses de secours des mines», Le Réveil du Nord, 19-10-1909.

100 LlaneZA ZApico, Manuel «Ante los grandes problemas», El Minero de la Hulla, octubre de 1916, recogido en: Llaneza, Manuel, Escritos..., pág. 92.

${ }^{101}$ La Voix du Mineur, 27-8-1910, pág. 2.

${ }^{102}$ La Voix du Mineur, 27-3-1909, pág. 3.

103 Société Houillère de Liévin, Eunres Sociales. Expo Roubaix 1911, Douai, 1911, págs. 27-35 y 39-51. 
En el ámbito lúdico, existían, por ejemplo, sociedades musicales o de arqueros, con gran tradición en la zona ${ }^{104}$. Pero sin duda la piedra angular de todo el entramado la constituían los alojamientos, que se habían ido mejorando en la esperanza de emplearlos como elemento generador de consenso social (ver imagen 5$)^{105}$. Por tanto, el fundador del SOMA conocía perfectamente las estrategias paternalistas, era consciente de la necesidad de combatirlas y sabía cómo hacerlo.

\section{IMAGEN 5. CITE DES GARENNES, CONSTRUIDA EN 1907}

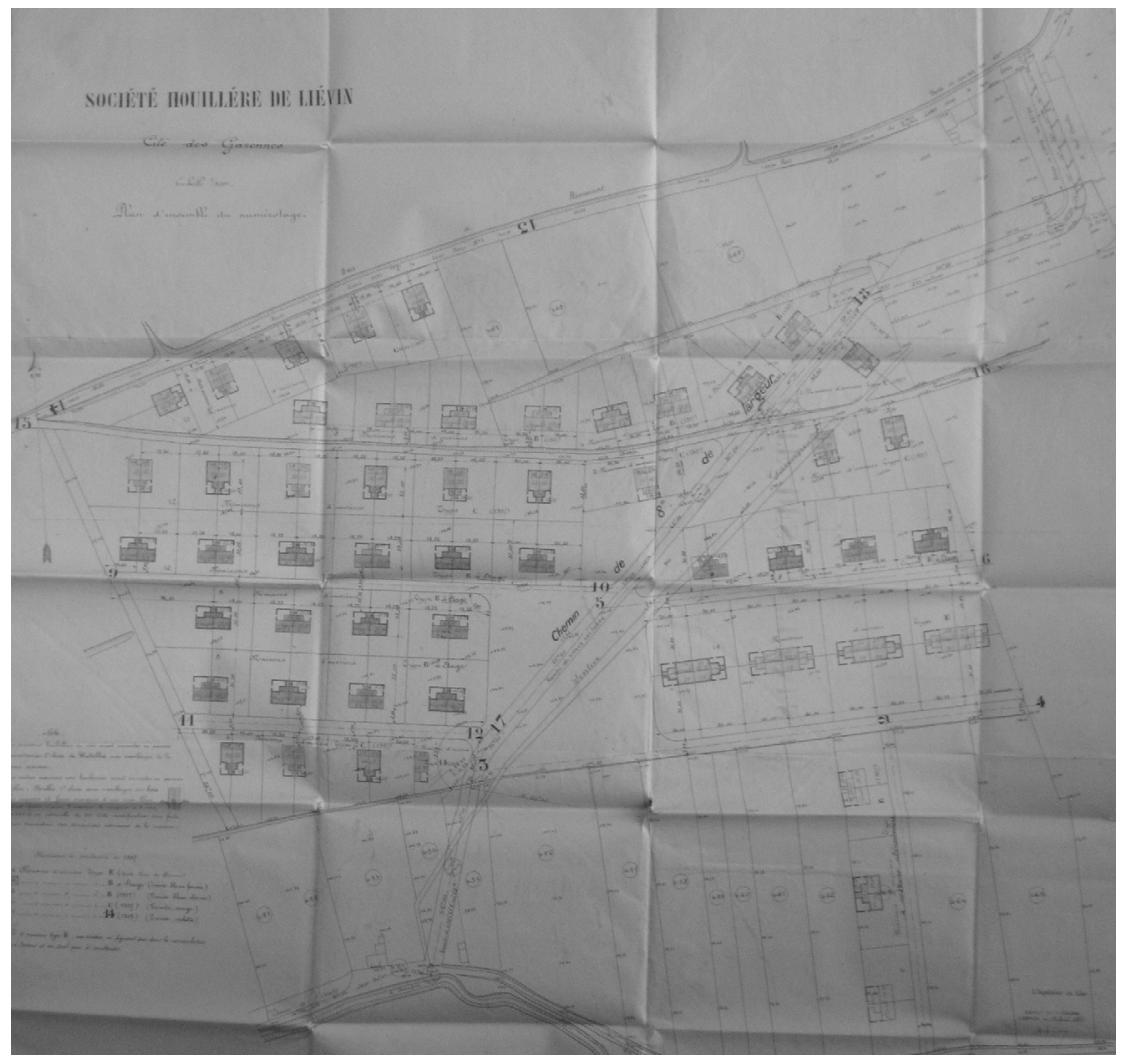

Plano de una cité de la Sté. Houillère de Liévin en la época en que Llaneza vivió allí. Obsérvese el tipo evolucionado de los alojamientos, pareados dos a dos y con una amplia parcela de terreno. Centre des Archives du Monde du Travail, 40 AS 261.1.

104 Société Houillère de Liévin, Euvres Sociales. Expo Roubaix 1911, Douai, 1911, pág. 58, y Société Houillère de Liévin, Note pour les actionnaires. Exercise 1909-1910, Douai, 1910, pág. 117.

105 Al respecto, Société Houillère de Liévin, Euvres Sociales. Expo Roubaix 1911, Douai, 1911, págs. 14-17 ; Société Houillère de Liévin, Note pour les actionnaires. Exercise 1908-1909, Douai, 1909, pág. 113. 
Este programa reformista, gradualista, posibilista y confiado en la acción estatal será pronto coronado por una aspiración lógica en este marco: la nacionalización de las minas ${ }^{106}$. El deseo no era nuevo, pero se verá refrendado en el congreso nacional de mineros celebrado en Lens, la ciudad de Basly, en mayo de 1909 y que Llaneza debió seguir con interés ${ }^{107}$. La petición de nacionalización se produce también en Asturias cuando el fin de las condiciones especialmente favorables que supuso la neutralidad española en la Primera Guerra Mundial —debido al consumo de los ejércitos y a la paralización de las principales cuencas hulleras competidoras - dejó de nuevo al aire las miserias de una minería poco competitiva ${ }^{108}$. Llaneza contemplaba como solución definitiva y de alguna manera continuación lógica de la intervención estatal que se venía reclamando y a menudo obteniendo- la opción estatalizadora, que plasmará en 1921 en un «Proyecto de Ley de Bases para la nacionalización de las minas de hulla en España». En él defendía una fórmula de gestión que reservaba un amplio papel a los propios obreros, que, obviamente, deberían desempeñarlo a partir del encuadramiento del sindicato ${ }^{109}$.

Curiosamente, en ambos casos se producirá la nacionalización, pero en condiciones muy diferentes. En Francia, tras la Segunda Guerra Mundial, como fórmula para garantizar el control estatal de un sector clave aún. En Asturias, sin embargo, se hará en 1967, ante la inviabilidad de la minería en el nuevo contexto de liberalización económica y con la intención de evitar una quiebra social, porque estaba fresco en la memoria el desafío al régimen de las huelgas mineras de $1962-63^{110}$. A la vez, la solución a adoptar debía satisfacer los intereses de un empresariado al que se le pagó un negocio ruinoso y conscientemente descapitalizado a precio de oro ${ }^{111}$. En resumen, lo que se hizo en España fue socializar pérdidas.

106 CoOper-Richet, La Fédération..., pág. 435.

107 «Le Congrès National des mineurs», Le Réveil du Nord, 20-5-1909. Días después, Basly publicaba un artículo en el que acusaba a la Cie. des Mines de Marles de negligencia, de pensar sólo en los dividendos y de falta de inversión y pedía al Estado que recuperara la concesión, es decir, que la nacionalizara, BASLY, Émile, «Marles», Le Réveil du Nord, 9-9-1909. En la misma línea, Fourniere, E., "Les mines \& leurs profits», Le Réveil du Nord, 17-11-1909 y BASLY, Émile, «La question minière», Le Réveil du Nord, 27-7-1910.

108 García Delgado, José Luis, «La economía española entre 1900 y 1923», en: TUÑóN DE LARA, Manuel (dir.), Historia de España, vol. VIII, Barcelona, Ediciones de Bolsillo, 1977.

109 PÉrez Ledesma, El obrero..., pág. 250. Véase el proyecto en LlaneZA ZAPICO, Manuel, Estudio de la industria bullera española y la necesidad de su nacionalización: proyecto de una Ley de bases para la nacionalización de las minas de bulla de España, Oviedo, SOMA, 1921. Explica sus motivaciones en LlANEZA ZAPICO, Manuel, «El problema del carbón», El Socialista, 28-8-1919, recogido en: LLANEZA, Escritos..., págs. 268-269.

110 Sobre el particular, Vega García, Rubén (coord.), Hay una luz en Asturias: las buelgas de 1962, Gijón, Trea, 2002.

111 El futuro presidente de la Confederación Española de Organizaciones Empresariales (CEOE), Carlos Ferrer Salat, declaró al poco tiempo que «[...] algunos propietarios de minas 
El pragmatismo del VS le llevó con frecuencia a compartir trinchera con la patronal, cuando se trataba de obtener del gobierno ventajas para la minería de Nord - Pas-de-Calais, mostrando un corporativismo regionalista fuera de toda duda $^{112}$. Esto servía a los intereses de las compañías, que con la ayuda del sindicato podían más fácilmente obtener desde aranceles proteccionistas hasta la construcción del Canal del Norte para colocar su carbón en París a precios competitivos respecto a la hulla inglesa ${ }^{113}$. Indirectamente, y con el plácet de las empresas, Basly conseguía convertir parte de esas ventajas arrancadas al Estado en nuevos beneficios para los mineros, aumentando así su prestigio en detrimento de opciones menos dispuestas a la transacción, como el JS. Para algunos autores, esta práctica forma parte del mismo pacto que los citados acuerdos de Arras, en los que las compañías ofrecían algunos avances a cambio de una paz social que el sindicato se esforzaba en conseguir ${ }^{114}$.

Este corporativismo se encuentra también en el SOMA ${ }^{115}$. Especialmente, una vez desaparecidas las circunstancias favorables de la Gran Guerra y en plena ofensiva patronal para recortar costes de producción a costa de las conquistas obreras de los años anteriores. En este contexto, Llaneza se adhería firmemente al lobby creado contra la intención del gobierno de rebajar los derechos aduaneros del carbón ${ }^{116}$. Así lo expresaba con claridad cuando se preguntaba retóricamente

Nosotros, ¿qué debemos hacer? ¿Emprender nuestra lucha contra el patrono? Nuestra lucha contra el patrono la sostendríamos un mes, dos, diez; pero al fin no sacaríamos beneficio alguno, puesto que éste no está en condiciones de poder darnos lo que nosotros le pidiéramos. Nuestra lucha debe ir contra el Estado, pues éste debe ser el que debe proteger nuestras minas, si quiere conservar la in-

integradas en Hunosa me han dicho, más o menos confidencialmente, que si hubiesen sabido el precio que el Estado les iba a pagar, hubiesen comprado antes muchas otras minas», Actualidad Económica, 16-5-1970. Para una visión más amplia de esta nacionalización en beneficio de los empresarios mineros, véase VV. AA., El fraude de Hunosa. Génesis y desarrollo. Alternativa a una crisis permanente, Madrid, Adra, 1981.

112 Gillet, Marcel, Les Charbonnages du Nord de la France au XIXe siècle, Paris, Mouton, 1973, pág. 331. Esta obra resulta insoslayable para adquirir una visión de conjunto y sin embargo profunda de la evolución de la minería de la hulla en el Norte de Francia a partir de una perspectiva económica no falta de referencias sociales.

113 LE MANER, «Un pionnier...», pág. 43.

114 Michel, Émile Basly..., pág. 86.

115 Por ejemplo, en la polémica sobre la tasa del carbón que beneficiaba a las minas de Puertollano y Peñarroya perjudicando a las asturianas, El Noroeste, 26-12-1916, pág. 1.

${ }^{116}$ Ya en 1919, la Asamblea de Municipios Hulleros de Asturias, de la que Llaneza era presidente como alcalde de Mieres, envió a Madrid una comisión para tratar de obtener exenciones fiscales y mejoras en los transportes. Poco después, patronal y SOMA se dirigían conjuntamente al gobierno para solicitar la libre exportación de carbones en vista de la acumulación de excedentes, MORADIELLOS, El Sindicato..., pág. 61. 
dependencia del país garantizada (...). En cambio, nuestro Gobierno, lejos de proteger, lo que hace es gravar con impuestos nuestra producción ${ }^{117}$.

Sin dejar de criticar la ausencia de reinversión de los beneficios de la guerra que podría haber hecho más competitivo el carbón asturiano mediante la modernización de las minas y sin cesar de pedir el mantenimiento de los niveles salariales y la inversión en formación para los obreros, el líder del Sindicato Minero se convirtió en una de las principales voces demandando barreras arancelarias que salvaran el sector ${ }^{118}$. De hecho, la actuación del SOMA al lado de la patronal bien podría ser una de las causas que expliquen la inexistencia de una opción política regionalista como las que en esa época crecían en otras zonas del país con intereses económicos diferenciados que defender.

Evidentemente, este entendimiento era tachado de colaboracionista por los sectores más a la izquierda ${ }^{119}$, hasta el punto de constituir una de las causas desencadenantes de la escisión comunista, que desembocaría en la creación en 1923 del Sindicato Único de Mineros de Asturias (SUM), apoyado también por anarquistas. Esta organización llegará a tener una implantación llamativa en el valle de Turón, pero no en otros lugares ${ }^{120}$. De hecho, el SOMA sólo perderá su hegemonía entre los mineros asturianos en la última etapa del franquismo, ya en los años sesenta, a diferencia de lo que sucede con el VS en Francia, que se ve sobrepasado tres décadas antes ${ }^{121}$. Sería también interesante, dentro de este cuadro de coincidencias que se está apenas apuntando, tratar de explicar las causas del diferente arraigo del movimiento comunista en ambas regiones en las décadas centrales del siglo. Pero esta es otra compleja línea de investigación a explorar que sobrepasa los objetivos de este artículo.

\section{CONCLUSIÓN}

El azar quiso que Manuel Llaneza pasara dos años de su vida en el Norte de Francia, donde conoció una cuenca hullera no muy diferente de la asturiana en geología y sistemas de explotación. Sin embargo, desde el primer instante pudo

\footnotetext{
117 Recensión de conferencia de LlANEZA ZAPICO, Manuel, Revista Industrial y Minera Asturiana, 154 (1-10-1921), pág. 301, cit. en: Moradiellos, El Sindicato..., pág. 72.

118 «Una conferencia de Llaneza sobre la crisis minera», El Noroeste, 2-3-1921, pág. 2.

119 Moradiellos, El Sindicato..., pág. 72.

120 Álvarez, Ceferino, El Sindicato Único de Mineros de Asturias, Oviedo, KRK Ediciones, 2004.

${ }^{121}$ En torno al despertar del antifranquismo minero en los años sesenta, véase VeGA GARCía (coord.), Hay una luz... En Nord - Pas-de-Calais a mediados de los treinta, como consecuencia de un proceso que se inicia una década antes, el PCF ya es mayoritario dentro de la izquierda en buena parte de la cuenca minera. Le MANER, Yves, «Les communistes du Nord et du Pas-de-Calais de l'agonie du front populaire à la guerre (1938-1939). La montée en puissance et «les grèves du Nord» de novembre 1938», Revue du Nord, 278 (1988).
} 
comprobar que la situación de los obreros que allí trabajaban era sensiblemente mejor y que éstos se organizaban de una forma distinta a lo que era acostumbrado en España. A su vuelta a Asturias en 1910 fundó el SOMA, un sindicato de industria y fuertemente centralizado que poco tenía que ver con las organizaciones anteriores, locales y de oficio. Aplicó el análisis de las coyunturas económicas, políticas y sociales para determinar su línea de actuación. Intentó siempre evitar las huelgas, haciendo gala de un moderantismo acusado, y trató ante todo de preservar la organización, confiando para ello en la negociación sistemática e institucionalizada. Apeló a la acción legisladora para conseguir avances. Introdujo ex novo una política asistencial destinada a erosionar la hegemonía social de las compañías mineras y a crear no sólo militantes, sino una cultura política y sindical más amplia. Hizo gala de un indudable corporativismo y tomó parte en el lobby hullero para conseguir del gobierno medidas favorables para el sector...

Si se tiene en cuenta que todo esto estaba lejos de lo que había en la región en 1908, cabe deducir que en un altísimo porcentaje estas innovaciones trascendentales se deben a la influencia del Vieux Syndicat. Se puede pensar incluso que, en ausencia de otros cambios relevantes en el ámbito social, político o técnico a la altura de 1910, son precisamente los conocimientos adquiridos por Llaneza en Francia los que hacen al sindicalismo asturiano tomar carta de naturaleza, superando la debilidad y los balbuceos previos. Sería cándido pretender que el socialista langreano fue ajeno a otras influencias o no estuvo marcado por experiencias posteriores, pero lo que parece innegable es que su estancia en Pas-de-Calais le hizo capaz de organizar el primer sindicato de industria del país y de marcar una serie de importantes hitos en la evolución del movimiento obrero español. 